\title{
FIFTY YEARS OF WHITE CLOVER RESEARCH IN NEW ZEALAND
}

J.L. Brock, J.R. Caradus and M.J.M. Hay Grasslands Division, DSIR, Palmerston North

\begin{abstract}
The importance of white clover in New Zealand pastoral agriculture cannot be overstated. It is the major source of nitrogen and by its presence improves pasture quality and balances seasonal growth of grass species. Because of its importance a considerable effort has been put into research on white clover over the past $\mathbf{5 0}$ years in New Zealand. This assay reviews the major advances made in white clover use and research from an historical perspective and summarises current understanding and possible future developments.
\end{abstract}

Keywords: white clover, review, history, soil fertility, $\mathbf{N}$ cycling, $\mathbf{N}$ fixation, nutrition, growth, population structure, management, performance, breeding, pests and diseases, quality.

\section{INTRODUCTION}

Today, white clover (Trifolium repens L.) is recognised as perhaps the most important forage legume in the temperature zones of the world. While producing high quality feed, its principal role lies in its ability to efficiently supply the large quantities of nitrogen $(\mathrm{N})$ essential to sustain highly productive pastures. New Zealand is particularly fortunate in that its temperate climate is generally conducive to strong white clover growth, in most of the intensively farmed regions of the country.

This essay is a subjective account of the development of white clover research in New Zealand. In taking the view of white clover as the basic driving force behind most of the processes involved in pasture production, either directly or by inference, in-depth treatment of all topics is not possible or realistic. The following is a summary of general themes and current positions within the various fields of knowledge.

\section{HISTORICAL}

During the early years of drystock farming in New Zealand (1870-1920) increased production came chiefly from expansion of land area, exploiting the natural fertility of the soils developed under native forest and tussock grassland. Little attention was given to improving pastures which were generally poor in agronomic performance and value, and deteriorated rapidly. Fertilisers (chiefly basic slag and water insoluble rock phosphates) were not widely used.

This changed in the 1920s. The First World War had stopped the import of basic slag, but the formation of the British Phosphate Commission in 1920 guaranteed a source of cheap phosphate, and general acceptance of superphosphate fertiliser had occurred by around 1925.

Already the early pioneers of agricultural research had foreseen the need for improved plant species and registration of pedigree seeds. Clovers were recognised as a key to progress. Fuelled by phosphate, the increased pasture production would be utilised by increased stocking rate to recycle available nutrients (particularly $\mathrm{N}$ ) and promote soil fertility. With these principles as a foundation, and aided by a government that financed agricultural instruction and research, the stage was set for further increases in production through 
intensification of land use. From the late 1920s, average camying capacity increased from $2.5 \mathrm{su} / \mathrm{ha}$ ( $1 \mathrm{su} / \mathrm{ac})$ to $8 \mathrm{su} / \mathrm{ha}(>3 / \mathrm{ac})$ by 1950.

Early work centred around advising. The results of widespread field trials, conducted to provide better information and planning of fertiliser topdressing, were extended into farming through a vigorous programme of lectures and field days. Thus the strong ecological base of grassland research and extension continued through the 1930s and 40s. Since the Second World War, a rapid expansion in agricultural science has been matched by impressive increases in farm productivity.

\section{SOIL FERTILITY, N CYCLING AND N-FIXATION}

These early agriculturalists recognised that white clover was not a pioneer legume and in order to utilise its $\mathrm{N}$-fixing potential, adequate supplies of limiting nutrients phosphorus $(P)$ and sulphur $(S)$ and rhizobia must be ensured. That was only the first step and had to be followed by an increase in stocking rate to utilise the increased pasture growth, to convert and transfer the clover $\mathrm{N}$ in forms available to the grass, thus stimulating the process of soil fertility building as a result of increased soil organic matter (SOM) quantity and/or quality. Four phases to soil fertility building have been identified, through (1) the introduction and establishment of white clover with the removal of nutrient deficiencies (other than $\mathrm{N}$ ), followed by (2) a clover dominant phase of high $\mathrm{N}$-fixation inputs, then (3) as the $\mathrm{N}$ becomes more available a gradual change to grass dominance occurs culminating in (4) a pasture almost entirely of grass where production reaches a plateau. It was estimated that a threshhold stocking rate of a round $15 \mathrm{su} / \mathrm{ha}(6 / \mathrm{ac})$ was necessary to get the process of $\mathrm{N}$ cycling moving effectively.

Initially the inputs of $\mathrm{N}$ from $\mathrm{N}$-fixation can be very high (>600 $\mathrm{kg} / \mathrm{ha} / \mathrm{yr}$ ) as SOM increases rapidly. However, the grazing animal in digesting the herbage, separates carbon (C) from $\mathrm{N}$, loses much of the $\mathrm{C}$ through respiration, and retums most of the $\mathrm{N}$ to the soil in a readily available form. Over time, this lowers the $\mathrm{C}: \mathrm{N}$ ratio of the soil, increasing its $\mathrm{N}$-supplying power or fertility. As the grass component responds, clover growth and $\mathrm{N}$-fixation decline. Recent studies estimate that for developed pastures in New Zealand annual N-fixation inputs range from 100 to 350 $\mathrm{kg} / \mathrm{ha}$ (mean 185). Reversion of formerly high producing pastures once the initial fertility of the bush burn had been depleted, was often caused by a failure to understand the nutrient and management requirements of clover. This was particularly important in hill country where fertilisers could not be easily applied to maintain the clovers. Many such 'reverted' pastures dominated by low fertility grasses were low in available nutrients only because they were bound up in stable SOM of the mor type. Such soils, while high in total soil $\mathrm{N}$, were low in available $\mathrm{N}$ because of wide $C: N$ ratios (poor quality). Development of such soils may involve both increase in $\mathrm{N}$ input from fixation (30-I $35 \mathrm{~kg} / \mathrm{ha} / \mathrm{yr}$ ) and increase in availability of $\mathrm{N}$ by conversion of SOM to the mull type (high quality) often with an accompanying fall in $\mathrm{C}: \mathrm{N}$ ratio and total SO $\mathrm{M}$.

In order to maintain a steady state of production (phase 4 pasture) all factors need to be in balance, and any losses of $\mathrm{N}$ from the system (leaching, volatilisation, denitrification) should be balanced by $\mathrm{N}$ fixation inputs. Modelling studies have indicated that high producing dairy farms could be in negative $\mathrm{N}$ balance, with losses exceeding inputs as illustrated by the chronic seasonal $\mathrm{N}$ deficiency (urine patch response) exhibited by many such high producing grass-dominant pastures. A reappraisal of the role of the grazing animal has suggested that maintaining an active legume component through defoliation may be more important than cycling 
nutrients. Transfer of $\mathrm{N}$ to the soil via decay of plants parts could be as important as through animal excreta.

\section{$\mathrm{N}$-fixation and mineral $\mathrm{N}$}

Clearly, clover growth, $\mathrm{N}$-fixation and available soil $\mathrm{N}$ interact strongly. Studies in the 1950s showed that rate of $\mathrm{N}$-fixation was directly dependent on the growth rate ( $\mathrm{N}$ demand) of the host plant (white clover) at any given available $\mathrm{N}$ level. Newer techniques with greater sensitivity for measuring $\mathrm{N}$-fixation (acetylene reduction and ${ }^{15} \mathrm{~N}$ dilution assays) have further shown that with two alternative sources of $\mathrm{N}$ (soil and fixation), clover will utilise soil $\mathrm{N}$ first if available, leaving $\mathrm{N}$-fixation to satisfy any remaining demand, and that both uptake of mineral $\mathrm{N}$ and $\mathrm{N}$-fixation can occur together. Where no mineral $\mathrm{N}$ is available there is a direct linear relationship between growth and $\mathrm{N}$-fixation rates, but as mineral $\mathrm{N}$ supply increases, $\mathrm{N}$-fixation rate decreases, until the mineral $\mathrm{N}$ supply is exhaused where-upon $\mathrm{N}$-fixation will return to its linear relationship with growth.

Any factor influencing growth rate of the clover and/or mineral $\mathrm{N}$ supply will alter the $\mathrm{N}$-fixation rate. The reduction in clover growth through competition from companion species for space will be partially offset by reduction in available soil $\mathrm{N}$ by grass uptake depending on the $\mathrm{N}$ status of the system. Summer soil moisture stress and cool temperatures in winter affect 'efficiency' of $\mathrm{N}$-fixation ( $\mathrm{kg} \mathrm{N}$ fixed/ unit growth), typically low in summer and high in winter. Many pests and diseases can have large effects on clover growth and $\mathrm{N}$-fixation, particularly root nematodes.

\section{INOCULATION}

The fixation of atmospheric $\mathrm{N}$ into plant available forms occurs in the nodules formed on the white clover roots after their infection by the bacterium Rhizobium trifolii. In this association the host plant supplies energy and nutrients for the Rhizobium which in turn benefits from the $\mathrm{N}$ fixed by the Rhizobium. This successful symbiosis underpins the $\mathrm{N}$ economy and productivity of pastures in New Zealand.

White clover is an introduced species, and as there are no effective native rhizobia in New Zealand soils, they have to be introduced. Many early pasture failures or slow establishment were attributed to lack of effective rhizobia, and unless white clover has been successfully grown in any given area, effective strains of rhizobia must still be introduced by inoculation of the seed at sowing.

An early practice to ensure effective rhizobia were present was to scatter soil from an established pasture at sowing. In 1933 tests began on the usefulness of inoculating white clover using one strain isolated from one plant, but results were variable. In 1945, trials using a wide source of strains started, and developed into the present certification scheme for legume inoculants established in 1955 and maintained by Plant Diseases Division of DSIR. Methods of culturing rhizobia centred around the peat culture technique which provided cultures with extended life of several months under refrigeration for commercial use.

The impetus for much of this work came from research in establishing pastures in new and difficult environments, primarily on the pumice soils of the volcanic plateau and later on the gumlands of Northland and the tussock grasslands of the Te Anau basin. However, the viability of rhizobia inoculated on to bare seed was poor if sowing was delayed, and methods to extend their useful life were researched. This resulted in the use of a methyl cellulose sticker with a Gafsaphosphate and dolomite pellet as the best combination. This provided both a physical barrier between the rhizobia and the environment and a neutral nutrient source for the rhizobia and the seed, and formed the basis of the successful commercial legume inoculation and pelleting industry of today. 
Since then research has endeavoured to improve $\mathrm{N}$-fixation capacity by developing superior rhizobia strains, as many strains now naturalised in our soils are not fully effective. The introduction of these new superior strains is difficult. Resident populations quickly compete with and soon replace the introduced strains. Genetic engineering to increase specificity between host plant and rhizobia appears to offer the most promising approach to solving this problem.

\section{Soil nutrient supply}

\section{NUTRITION}

While the importance of the major macro-nutrients such as $\mathrm{N}, \mathrm{P}, \mathrm{K}$ and $\mathrm{S}$ has long been known, it was not until the 1930s that nutrient culture techniqes were sufficiently developed to critically assess the importance of the essential macro-and micro-nutrients for plant growth. Most of this work was conducted overseas, and the main empasis in New Zealand concerned the classification and mapping of soils and any accompanying nutrient deficiencies. By the early 1960s a large volume of information from field trials and laboratory tests was available to form the basis for interpreting comprehensive soil and plant testing for the recommendation of appropriate fertiliser requirements to farmers.

Phosphorus deficiency was early recognised as a widespread problem limiting production on many New Zealand soils. Fortunately the ready availability of relatively cheap superphosphate fertiliser from 1920 made treatment of this deficiency possible, although widespread application was restricted by the technology available. It was not until the 1950 s when aerial topdressing extended the use of fertiliser into larger areas of hill country, that $S$ deficiency was found to be as widespread and as important as $P$ deficiency, but the high $S$ content of superphosphate had usually been adequate to correct this deficiency. Most other macro-nutrients are in adequate supply in New Zealand soils apart from areas of $\mathrm{K}$ deficiency chiefly on volcanic soils. Calcium, although rarely deficient in soils, is added in the form of lime to ameliorate soil acidity, and serves as a soil conditioner, increasing the availability of nutrients, stimulating biological activity and providing suitable conditions for soil rhizobia, nodulation and $\mathrm{N}$-fixation.

In 1945, it was found that one of the micro-nutrients molybdenum (MO), was widely deficient in New Zealand soils, and the complex nature of the interaction between lime, P, S and MD, the 'lime sparing' effect, was elucidated in the 1950s. Molybdenum is particularly important for white clover, as it is essential to the nitrogenase enzyme responsible for $\mathrm{N}$-fixation in clover nodules. Other elements important to plant growth or $\mathrm{N}$-fixation but not generally deficient include copper, cobalt and boron.

In some conditions toxicity of elements can be a problem for white clover. Manganese $(\mathrm{Mn})$ can be antagonistic to $\mathrm{Mb}$ particularly in high rainfall areas, and similarly on acid soils, aluminium (Al) toxicity can reduce white clover growth by restricting $\mathrm{P}$ and $\mathrm{Ca}$ uptake. Both problems can be overcome by application of lime to raise soil $\mathbf{p H}$, or large applications of $\mathrm{P}$ in the case of $\mathrm{Al}$.

During the 1960s considerable research went into determining critical levels of nutrients in pastures as an alternative diagnositic tool to soil testing for making fertiliser recommendations for farming. However, variation caused by factors such as climate, plant organs, maturity and interactions with other nutrients makes interpretation of data difficult, reducing its usefulness.

The energy crisis of the 1970 s and the economic downturn in farming of the 1980 s caused a considerable reduction in the use of superphosphate fertiliser. Initially high analysis fertilisers were produced to improve the economics of application, and latterly research on the use of rock phosphates as an alternative has increased. 


\section{Nutrient uptake and use}

In New Zealand research has concentrated on $\mathrm{P}$ uptake and metabolism. Root morphology is of importance to mineral nutrient uptake. Research in the 1950s and 1960s showed that plants with densely branched, fine roots with long root hairs and low cation exchange capacity (CEC), and which can also adapt by reducing shoot:root ratio in times of nutrient shortage, are strong competitors for nutrients. White clover has a relatively short, thick and low branching root system with short root hairs and high CEC, and an inflexible shoot:root ration, and is therefore poorly equipped to compete with most grasses for nutrients. In mixed swards, in order to maintain white clover growth, additional nutrients ( $\mathrm{P}, \mathrm{K}$ and $\mathrm{S})$ must be applied. Raising the $\mathrm{pH}$ by liming can alter root morphology, increase root hair length and stimulate branching, resulting in increased uptake of P. In the 1970 s, attention turned to the root infecting vesicular arbuscular mycorrhiza which can cause increased uptake of P. However, this appears to be of benefit only at low levels of soil P. Plants with short root hairs tended to be more mycorrhizal than those selected for long root hairs.

Emphasis shifted to variation in white clover root morphology in the 1980s. In general, large-leaved types of plants tend to have deeper more tap-rooted systems, and small-leaved plants fibrous shallow roots. Populations adapted to low P soils tend to have finer, shorter and slower elongating roots but with a greater response to $\mathrm{P}$, than those of populations adapted to high $\mathrm{P}$ soils. No variation in CEC between these two population groups has been found. It has been shown that clover stolons can also absorb $\mathrm{P}$ (and $\mathrm{K}$ ) directly from the soil. With large amounts of stolon being buried by treading and wormcasting activity, particularly during winter, they are in an ideal position to compete for $\mathrm{P}$ deposited through topdressing or made available in surface worm casts by enzymatic action while passing through the earthworm gut.

In New Zealand, studies on the movement of ions across membranes into white clover roots include the kinetics of ion transport and its coupling to energy sources. Comparative studies have shown that the capacity for $\mathrm{K}$ absorption was 5 times higher in ryegrass than white clover roots. Both $\mathrm{P}$ and $\mathrm{K}$ appear to be coupled to $\mathrm{H}^{+}$ ion transport across the cell membrane and is therefore partly dependent on membrane electropotential in which $\mathrm{pH}$ is an important factor.

Phosphorus is a mobile element and is distributed to various parts of the plant according to sink strength. It exists in both inorganic form, usually in the vacuole as a buffer against decreased $\mathrm{P}$ supply, and in organic form as nucleic acids, esters and lipids. Translocation is strongly acropetal, moving to the growing points and young leaves, and root meristems and nodules.

\section{Herbage quality}

Considerable study on the nutritive value of, and disorders caused by, white clover on grazing animals has been conducted in New Zealand.

With high levels of crude protein and a high ratio of soluble to structural carbohydrate, white clover herbage provides feed of higher quality than grasses and most other legumes. Compared with perennial ryegrass, digestion time of white clover is shorter and voluntary intake is greater particularly with sheep, although cattle tend to dislike white clover as a pure feed. Generally the mineral content of white clover is higher than that of grasses, particularly in $\mathrm{Ca}, \mathrm{Mg}$ and $\mathrm{P}$, although sodium ( $\mathrm{Na}$ ) may be low. Liveweight gains of lambs fed on white clover exceeds those fed on any other herbage type. These quality aspects of white clover are generally not being exploited, being regarded as subsidiary to its dominant role of $\mathrm{N}$-fixation inputs and soil fertility building. Nevertheless producing pastures of higher white clover content by manipulation with class of grazing animal and/or selective herbicides may be advantageous and needs further evaluation, 
The only major disorder to detract from white clover value is bloat in cattle. This is caused by the formation of stable protein foam complexes in the rumen as a result of the highly soluble nature of the high quality constituents of the herbage. Plants containing condensed tannins (lotus, sainfoin) form insoluble complexes with plant protein and prevent bloat. Efforts to find white clover plants containing tannins in the herbage or produce hybrids with species containing tannins have been unsuccessful to date, and bloat remains a major problem.

\section{PLANT PRODUCTIVITY AND PERSISTENCE}

Most work on white clover in New Zealand during the 1930s and 40s was concerned with selection for improved productivity and persistence under grazing within the established species and cultivars available. By the 1950 s carrying capacity had trebled, putting these plants under greater pressure. In order to continue improvement of plant type and develop soundly based management systems to cope with these situations, it was realised that more information on basic physiological and morpholigical responses of pasture species, including white clover, to changes in their environment (light, temperature and defoliation) was needed. Aerial topdressing was extending the use of white clover to more varied and difficult environments. In unploughable hill country, oversowing of seeds by aircraft gave variable and often negligible results. Research into pasture establishment methods using intensive grazing and treading by stock to break up the mat of low fertility species to provide a suitable seedbed and reduce competition for establishing seedlings began and continues today, incorporating the use of (selective) herbicides. The importance of buried hard seed in maintaining the white clover component and the use of the grazing animal to spread white clover into new areas have been demonstrated. In lowland established pastures white clover proved more susceptible to treading than most grasses in summer and winter, particularly under wet conditions, which led to devising management practices aimed at minimising adverse treading effects.

\section{Plant physiology and growth}

Controlled environment studies in the 1950's delineated the light and temperature responses of many pasture plants. The optimum temperature for growth of white clover was higher $\left(24^{\circ} \mathrm{C}\right)$ and broader $\left(1630^{\circ} \mathrm{C}\right)$ than for ryegrass $\left(18-21^{\circ} \mathrm{C}\right)$, and different parts of the shoot of white clover had different response curves and optima. For instance, stolon elongation was greater at higher temperature, but branching increased as temperature declined. Increasing light increased rate of leaf appearance, duration of leaf expansion, leaf size and stolon branching. However, the interaction of light and temperature of various vegetative processes were more complex, and along with the effects of light quality were examined over 1958 to 1965.

At the same time, field studies were defining the principles of leaf appearance and morphology and the effects of defoliation. In undisturbed white clover, the prevailing temperature and light controlled the number and size of leaves, and the size of stolons and their rates of development. Similar results were found in mixed swards. After defoliation of pasture, regrowth of plants involved the reestablishment of an equilibrium between light and temperature and the numbers and size of leaves present. Because of the horizontal arrangement of leaflets, white clover could re-establish its leaf area after grazing and intercept and utilise light more quickly than tyegrass, but as regrowth interval increased the advantage moved to the erect leaves of ryegrass.

During these and overseas studies, the importance of the growth of the stolon in relation to the production and persistence of white clover was demonstrated. This 
concept was used in the selection and breeding of the hill country cultivar 'Grasslands Tahora' in the 1970s, and initiated interest in studies on the growth of stolon systems under sheep grazing. A hill country study found a strong seasonal pattern of leaf and stolon production and death, with low rates in winter and higher rates in other seasons which were governed by soil moisture.

Emphasis in the 1980s has turned towards whole plant sutdies. Clover populations follow a seasonal pattern of death and renewal which can affect persistency. During winter treading and earthworm activity combine to bury in excess of $90 \%$ of clover stolons, and new stolons must be re-established on the soil surface over spring and summer. At most times of the year the processes of new stolon formation and old stolon death are in balance and the structure of the population of white clover remains relatively constant. During spring there is change, with stolon death exceeding formation, so that plants reduce in size and complexity, larger plants breaking up into several smaller ones, before the quilibrium is re-established over summer. At this point the plant population is fragile and susceptible to mismanagement or environmental stress such as early drought. Throughout the year the range in plant size within the population is large and log normally distributed. Density of plants was around $440 / \mathrm{m}^{2}$, tending to be higher in pastures of higher clover content.

The main differences between plants growing under contrasting management systems (set stock $\boldsymbol{v}$, rotational grazing) are in size only, the structure of the plants in terms of numbers of leaves, stolons, roots and branching complexity being similar. The primary factor in determining size was defoliation frequency, increasing intervals between defoliation allowing development of larger plant organs.

\section{Management}

Using these principles of plant growth, basic strategies for maintaining plant productivity and species balance in mixed ryegrass/white clover swards were developed. In general, close frequent defoliation favours white clover and lax infrequent defoliation encourages ryegrass. Using the different temperature responses, management systems were devised to enhance the complementarity of the summer-autumn growing white clover and winter-spring dominant ryegrass. This consisted of frequent close defoliation (set-stocking if possible) in spring to reduce ryegrass reproductive growth and increase clover density, followed by lax infrequent defoliation in summer to encourage white clover then a return to frequent close defoliation for a short period in mid-late autumn to reduce clover growth and promote winter ryegrass dominance. Overgrazing in summer is detrimental to white clover probably through a loss of stolon and productive growing points. Frequent defoliation in spring has equally important effects for clover in promoting ryegrass tiller density which can provide protection to clover stolons from summer overgrazing, when removal of pasture cover can expose stolons to killing levels of radiation. Open soil surface temperatures often exceed $45^{\circ} \mathrm{C}$ in drought conditions causing large scale stolon death. All cultivars, irrespective of morphological type, are equally susceptible.

Increased pasture utilisation was envisaged by the early scientists as being best accomplished by intensive rotational grazing, which appeared to stimulate the $\mathrm{N}$ cycle and soil fertility building to the greatest extent. Nevertheless, such grazing management may not be the most suitable once the grass dominant phase 4 pastures have been achieved. In predominantly intensive rotational grazing systems a combination of low density and severe physiological stress at grazing would reduce the ability of the plants to readily utilise the high return rate of mineral $\mathrm{N}$ from the grazing animal. Under suitable conditions this could lead to high losses from leaching in winter or volatilisation of ammonia in summer. Compensation by 
increased clover growth may not help as the clover will utilise the available $\mathrm{N}$ in preference to fixing $\mathrm{N}$. Set-stocking, on the other hand, with its regular but lenient defoliation pattern, promotes grass density, and reduces physiological stress allowing better utilisation of the lower rate of mineral $\mathrm{N}$ return from animal excret, hence reducing $\mathrm{N}$ losses. In such circumstances a high clover content in the pasture would not be needed. $\mathrm{N}$-fixation studies on grazed pastures support this view. The factors most important to $\mathrm{N}$-fixation after white clover growth rate, were those concerned with (a) mineral $\mathrm{N}$ availability (grass growth rate and soil mineral $\mathrm{N}$ uptake) for rotational grazing, and (b) plant growth (environmental factors soil moisture and evapotranspiration) for set-stocking.

\section{PESTS AND DISEASES}

While research has indicated a large number of pests and diseases colonise white clover, only a few have proven economic effects. Insects form an important group. The foliar feeding porina caterpillar (Wiseana spp.) of the southern North Island and South Island causes pasture damage during autumn and winter, with production losses occurring at densities above 20-40 larvae $/ \mathrm{m}^{*}$. Other foliar feeders of less importance are aphids (Acyrthosiphon sp.), lucerne flea (Sminthurus viridis) and field cricket (Teleogryllus commodus). The main root feeding insect of widespread occurrence is grass grub (Costelytra zealandica), most noticeable from late autumn to early spring depending on the density of white clover which the larvae prefer. Damage can be severe when larvae density exceed $100-200 / \mathrm{m}^{2}$. Although not so widespread, white fringed weevil (Graphognathus leucoloma) can also cause severe damage during autumn and early winter. In the absence of economic chemical control methods, biological control agents have been advocated as the most realistic alternative.

Collectively, the remaining pests and diseases have been demonstrated to have large effects on white clover growth and $\mathrm{N}$-fixation, but because their effects are largely subclinical and difficult to detect and quantify, they are largely unrecognised. One of the most important groups appear to be the root infecting nematodes. Clover cyst nematode (Heterodera trifolli) and root lesion nematodes (Pratylenchus spp.)are widespread, plus the root knot nematode (Meloidogyne spp.) in the North Island. Prevalent from late spring to autumn they have been shown to have considerable effect on white clover growth, $\mathrm{N}$-fixation and utilisation of applied phosphate. Attack by the stem nematode (Ditylenchus dipsaci) is primarily a problem during pasture establishment.

A large number of fungi have been shown to be pathogenic towards white clover, the most important being pepper spot (Leptosphaerulina trifolii), sooty blotch (Mycosphaerella killianii), pseudopeziza leaf spot (Pseudopeziza trifolii), sclerotinia clover rot (Sclerotinia trifoliorum) and rust (Uromyces trifolii). Of the several viruses found on white clover, only white clover mosaic virus (WCMV) may be of importance in the field.

\section{Cultivar development}

\section{BREEDING}

Up until 1940 most scientific research focused around the improvement of plant strain. The first significant identification of genetic variation within white clover in New Zealand idenitifed four major types of white clover found in New Zealand pastures.

Type 1: New Zealand Wild White No. 1. A highly productive medium leaved perennial found in fertile old pastures. It was highly cyanogenic.

Type 2: New Zealand Wild White No. 2. A perennial type, denser and smaller 
leaved than No. 1 and of lower productivity. It was less cyanogenic and was found on less fertile soils.

Type 3: Ordinary New Zealand White. A non-persistent form with reasonable first year growth and early profuse flowering, but poor second year growth. It had medium sized leaves and was predominantly acyanogenic.

Type 4: Lax early-flowering New Zealand and ordinary European. Nonpersistent, almost annual type, with low productivity, small leaves and acyanogenic.

The superiottiy of No. 1 type led to its certification in 1930 and commercial production. A breeding programme was then started to replace this unselected ecotype with pedigree New Zealand Certified Mother Seed. The variety was Progressively improved until 1957, when a final selection was completed. This was renamed 'Grasslands Huia' in 1964.

Since then many hundreds of white clover lines, have been evaluated, throughout New Zealand and in general:

- after the first year the majority of overseas material has poorer productivity and persistence than New Zealand cultivars.

- with time and increasing grazing pressure, the larger leaved forms generally decline in relative performance while some smaller leaved types improve.

- material of Mediterranean origin performs better in autumn and winter than Huia.

- lines with relatively high cyanogenesis levels tend to have the best agronomic performance in longer term trials,

- there are, however, a few outstanding introduced lines with potential most often through hybridising with New Zealand material.

As a result of this screening and selection three further cultivars have been released. 'Grasslands Pitau' was selected from hybrids between Huia and a Spanish line which exhibited excellent cool season growth, then backcrossed to Huia to regain the desired leaf density and agronomic performance. Pitau reflects the behavious of the Spanish parent with improved cool-season growth (late summer to late winter), particularly in the warmer North Island but only occasionally in the cooler South Island. As ladino cultivars showed greater resistance to stem nematode, and better summer production than both Huia and Pitau, genotypes of hybrids between Pitau and several ladino cultivars, predominantly Regal ladino, were selected to form the basis of 'Grasslands Kopu', a larger leaved cultivar, with agronomic characters suited to intensive lowland farming practices.

The problem of poor resistance of Huia in set-stocked hill country led to selection of high yielding genotypes from a collection of more than 2000 plants from 67 sites in moist hill country. These plants had higher stolon densities than Huia with a resulting lower harvest index, which however ensured better Persistence, and formed the basis of the third cultivar, 'Grasslands Tahora'.

A programme of breeding for specific regions whithin New Zealand has resulted in three promising experimental lines, an improved Huia type for Southland, a large leaved type incorporating Mediterranean germplasm for Northland dairy and cattle forms, and a smaller leaved type developed from collections made from Northland sheep farms.

The recent development of biotechology has provided the potential to introduce foreign genes into the white clover genome such as improved nutritional quality, pest resistance, viral resistance and herbicide tolerance, which are controlled by a few genes. 


\section{SUMMARY AND CONCLUSION}

The importance of white clover to New Zealand agriculture is attested to by the large volume of research devoted to improving its performance. Early agricultural scientists recognised its importance 60-70 years ago, providing farming with the sound base from which to launch the spectacular expansion in agricultural production witnessed up to the present day. By the early 1930s, the basic principles of stimulating white clover (and nutrient turnover) through use of $P$ fertiliser and high utilisation by the grazing animal were well established. After the Second World War, the explosion of technological development allowed scientific research to flourish.

Increased knowledge of the growth requirements of white clover has ensured its continuing use in New Zealand even as farming systems continue to intensify and diversify. Recently more productive cultivars for specific environments have been developed and this trend will continue. Grazing management should be a key element of the environment for breeding any new cultivars of white clover as it has a major modifying influence on most processes in pastoral systems. Not only does it influence plant growth and morphology, but also the nutrient economy of the pasture through changes in soil organic matter quantity and quality. Continued research on a broad front is required if white clover is to continue to underpin the efficiency of increasingly intensive pastoral systems in New Zealand.

There are several major areas of concern for white clover. Detailed ecologically based studies on the mechanisms of plant growth, including companion species (the effect of competition), will be required to help interpret differences between cultivars and provide models for development of new cultivars. With white clover being increasingly extended into marginal areas for its growth, programmes are being developed for improving persistence in dryland environments, and tolerance nutritional limitations such as lower $P$ levels (and high aluminium) in soils, and increasing efficiency of $P$ utilisation in the plant. For plant health, the most important areas are increasing resistance to root invading nematodes, and to a lesser extent to grass grub. With the importance of seed export of New Zealand white clover cultivars, particularly to colder European countries, programmes to increase tolerance to frost, high $\mathrm{N}$, and resistance to Sclerotinia clover rot are needed. The developing use of gene transfer techniques may be used in some of these programmes.

\section{General}

FURTHER READING

White Clover. (eds. M.J. Baker, W.M. Williams) CAB International UK, 1967 534p.

Brougham, R.W.; Ball, P.R.; Williams, WM. 1976. The ecology and management of white clover based pastures. In Plant relations in pastures. (Ed. J.R. Wilson). CSIRO, Canberra, Australia: 309-324.

Brougham. A.W. 1961. Pasture management and animal production. Proceedings NZ Grassland Association 42: 54-69.

Cockayne. A.H.; Levy, E.B. 1956. Grasslands of New Zealand. A Grassland Philosophy. B. Grassland Ecology. Proceedings of the Vith International Grassland Congress, Palmerston North, New Zealand: 585-610.

Frame, J.; Newbould, P. 1966. Agronomy of white clover. Advances in agronomy 40: 1-66.

Levy. E.B. 1970. Grasslands of New Zealand. Government Printer, Wellington.

Soil fertility, N cycling, $N$ flxation

Ball, P.R. 1979. Nitrogen relationships in grazed cut grass-clover systems. PhD Thesis, Massey University, New

Zealand.
Ball. P.R.; Crush, J.R. 1965. Prospects for increasing symbiotic nitrogen fixation in temperate grasslands. Proceedings of the XVIh International Grassland Congress, Kyoto, Japan:56-60.

Gandar, P.W. (Ed) (1960) nitrogen balances in New Zealand Ecosystems (Ed. P.W. Gandar). Proceedings of a workshop in nitrogen balances in terrestrial ecosystems in New Zealand, Palmerston North, N.Z. 1960. pp.260. 
Hoglund, J.H.; Crush, J.R.; Brock J.L.; Ball. P.R.; Carran, R.A 1979. Nitrogen fixation in pasture XII General discussion. NZ journal of experimental agriculture 7: 45-51.

Hoglund, J.H.; Brock, J.L. 1987. Nitrogen fixation in managed grasslands. In Management Grasslands. B. Analytical studies (R.W. Snaydon Ed.) Elsevier Science Publishers, B.V. Amsterdam. 187-96

Sears, P.D. 1953. Pasture growth and soil fertility. 1. the influence of red and white clovers, superphosphate. lime, and sheep grazing. on pasture yields and botanical composition. NZ journal of science and lechnology A35 (supplement 1): 1-29.

Sears. P.D. 1960. Grass/clover relationships in New Zealand. Proceedings of the 8 th International Grassland Congress. $130 \cdot 133$.

Sears, P.D.; Goodall, V.C.; Jackman, R.H.; Robinson, G.S. 1965. Pasture growth and soil fertility VIII. The influence Of grasses, white clover, fertilisers, and the return of herbage clippings on pasture production on an Impoverished soil. NZ journal of agricultural research 8: 270-83.

Sinclair. A.G. 1973. Non-destructive acetylene reduction assay of nitrogen fixation applied to white clover plants in soil. NZ journal of agricuitural research 16:263-70.

Walker, T.W. 1968. Changes induced in the soil by pastoral farming. New Zealand Soil Bureau Bulletin 26 (Part 1): $104-109$

Inoculation

Cullen, N.A. 1964. Pasture establishment problems at Te Anau. Proceedings NZ Grassland Association 26: 10914.

Greenwood, R.M. 1961. Pasture establishment on podzolised soil in Northland. III. Studies on rhizobia populations and the effects of inoculation. NZ journal of agricultural research : 375-89.

Hastings, A.; Greenwood, R.M.; Proctor, M.H. 1966. Legume inoculation in New Zealand. DSIR Information Series No. 58. pp.37

MacFarlane, M.J Bonish, P.M. 1986. Oversowing white clover into cleared and unimproved North Island hill country $=$ the role of management, fertiliser, inoculation. pelleting and resident white clover. Proceedings NZ Grassland Association 47: 43-51.

McKinnon, P.A., Robertson, J.G.; Scott, D.J.; Hale, C.N. 1977. Legume inoculant usage in New Zealand. NZ journal of experimental agriculture 5: 35-59.

Pankhurst, C.E.; Greenwood, R.M. 1983. Establishment and persistence of Phizobium trifolii in a developed pasture soil. NZ journal of experimental agriculture $I:$ 165-69.

Sears, P.D.; Hyde, O.C.; Greenwood, R.M. 1955. Pasture establihsment on pumice soils. NZ journal of science and technology A3 7: 11 0-40.

Nutrition

Caradus, J.R.; Snaydon, R.W. 1987. Aspects of the phosphorus nutrition of white clover. 1. Inorganic phosphorus content of leaf tissue. Jounal of plant nutrition 10: 273-86.

Bowling, D.J.F.; Dunlop, J. 1978. Uptake of phosphate by white clover. 1. Evidence for an electrogenic phosphate pump. Journal of experimental botany 29: 1139-85.

Clarke, R.T.J.; Reid, C.S.W. 1374. Foamy bloat of cattle. A review. Journal to dairy science 57: 753-85.

Crush, J.R. 1974. Plant growth responses lo vesicular-arbuscular mycorrhiza VII. Growth and nodulation of some herbage legumes. New phytologist 73. 743-49.

Crush, J.R.; Caradus, J.R. 1980. Effect of mycorrhizas on growth of some white clovers. NZ journal of agricultural research 23: 233-37.

Dunlop, J.. Hart, AL. 1987. Mineral nutrition. In White clover (Eds M.J. Baker, W.M. Williams) CAB International. U.K: 153.81.

During, C.; Lynch, P.B.; McNaught, KJ.; Scott. R.S. 1960. A study of the interaction of P, K, S, Mg, Mo and B fertilisers and ground limestone, applied to grass-clover pasture. NZ journal of agricultural research 3: 950 93

Hart, A.L.; Jessop, D.L.; Gaipin, J. 1981. The response to phosphorus of white clover and lotus inoculated with rhirobia or given $\mathrm{KNO}_{3}$. NZ journal of agricultural research 24: 27-32.

Hay. M.J.M.; Dunlop, J. 1982. Phosphate absorption by white clover stoions in pasture. NZ journal of agricultural research 25: 2 11-16.

Hoglund, J.H.. Brock, J.L. 1983. Effects of defoliation frequency and nitrogen and phosphorus nutrition on performance of 4 white clover cultivars. NZ journal of agricultural research 26: 109-I 3.

McNaught, KJ. 1970. Diagnosis of mineral deficiencies in grass-legume pastures by plant analysis. Proceedings of the XIth International Grasslands Congress: $344-38$.

Mouat, M.C.H. 1983. Competitive adaptation by plants lo nutrient shortage through modification of root growth and surface charge. NZ journal of agricultural research 26: 327-32.

O'Connor, M.D.; Ledgard, S.F.; Carruthers, M.P.; Upsell, C.; Feyter, C.; Edmeades, D.C. 1988. Results from the spring 1986 bloat survey: South Auckland-Waikato. Proceedings NZ Grassland Association 49: 167.68.

Powell, C.L.; Sithamparanathan, J. 1977. Mycorrhizas in hill country soils IV. Infection rates in grass and legume species by indigenous mycorrhizal fungi under field conditions. NZ journal of agricultural research 20: 489 94. 
Taylor. N.H.; Cunningham, I.J.; Davies, E.B. 1956. Soil type in relation to mineral deficiencies. Proceedings of the 7th International Grasslands Congress, Palmerston North, New Zealand: 357-67.

Ulyatt M.J. 1965. Pasture composition and animal production. In 'Ruminant physiology: Concepts nd Consequences: (Eds. S.K Baker, J.M. Gainthorne, D.B. Purser). University of Western Australia Perth: 195203.

Walker, T.W.; Adams, A.F.R.; Orchislon. H.D. 1955. The effects of interactions of sulphur, phosphorus, and molybdenum on the growth and composition of clovers. NZ journal of science and technology 36A: 470-

Physiology and growth

Brock. J.L.; Hay, M.J.M.; Thomas, V.J.;Sedcole, J.R. 1966. Morphology of while clover (Trifoliumrepens L.) plants in pastures under intensive sheep grazing. Journal of agricultural science, Cambridge 111: '273-83

Brougham. R.W. 1956. Leaf development in swards of white clover (Trifolium repens L.). NZ journal of agricultural research 1: $39-52$

Brougham. R.W. 1962. The leaf growth of Trifolium repens as influenced by seasonal changes in the light environment. Journal of ecology 50: 449-59.

Chapman, D.F. 1963. Growth and demography of Trifolium repens stolons in grazed hill pastures. Journal of applied ecology 20: 597-608.

Hart, A.L. 1967. Physiology. In White Clover (Eds. M.J. Baker, W.M. Williams). CAB International. UK: 125-52.

Hay, M.J.M.; Brock, J.L.; Thomas, V.J.; Knighton, M.V. 1966. Seasonal and sheep grazing management effects on branching structure and dry weight of white clover plants in mixed swards. Proceedings NZ Grassland Association 49: $197-202$

Mitchell, KJ. 1956. Growth of pasture species III White clover (Trifolium repens), subterranean clover (7. subterranean) and lotus major (Lotus uliginosus). NZ journal of science and technology 37A: 395-413.

Mitchell, KJ.; Lucanus, R. 1962. Growth of pasture species under controlled environment. IO. Growth at various levels of constant temperature with 8 and 16 hours of uniform light per day. NZ journal of agricultural research 5: 135-44.

Thomas, R.G. 1987. The structure of the mature plant. Vegetative growth and development. Reproductive tevelopment. In White clover (Eds. M.J. Baker, W.M. Williams) CAB International. U.D.: I-124.

Management

Brock, J.L.; Hoglund, J.H.; Fletcher, R.H. 1983. Effects of grazing management on seasonal variation in nitrogen fixation. Proceedings of the XIV International Grassland Congress: 339-41.

Brock J.L. 1966. Evauation of New Zealand bred white clover cultivars under rotational grazing and set stocking with sheep. Proceedings NZ Grass/and Association 49: 203-206

Brougham. R.W. 1960. The effect of frequent hard grazing at different times of the year on the productivity and species yield of a grass-clover pasture. NZ journal of agricultural research 3: 125-36.

Brougham, R.W.; Jackman, R.H. 1974. Clover nitrogen and pasture management. Dairy farming Annual, Massey University: $38-47$.

Edmond, D.B. 1966. The influence of animal treading on pasture growth. Proceedings of the Xth International Grassland Congress: $453-56$

Field, T.R.O.; Ball. P.R. 1962. Nitrogen balance in an intensively utilised dairy farm. Proceedings NZ Grassland Association 43: 64-69.

Harris, W. 1973. Ryegrass genotype - environment interactions in response to density, cuttingheight and competition with white clover. NZ journal of agricultural research 16:207-22.

Harris, W. 1987. Populations dynamics and competition. In White Clover (Eds. M.J. Baker, W.M. Williams). CAB International, UK; 203-98.

Suckling, F.E.T. 1950. Strike of oversown grass and clover seeds on hill pastures. NZ journal of science and technology 32A: $1-9$.

Suckling,F.E.T. 1952: Dissemination of white clover (Tritolium repens) by sheep. NZ journal of science and technology 33A: 64-77.

Suckling, F.E.T. 1959. Pasture management trals on unploughable hill country at Te Awa II. Results for 1951-57. NZ journal of agricultural research 2: 485-543.

Pests and diseases

Gaynor, D.L.: Skipp. R.A. 1987. Pests. In White Clover (Eds. M.J. Baker, W.M. Williams) CAB International, UK: 461-92.

Latch, G.; Skipp. R.A. 1967. Diseases. In White Clover (Eds. M.J. Baker, W.M. Williams) CAB International, UK: 421-60.

Skipp. R.A.; Gaynor, D.L. 1967. Pests - Naematodes. In White Clover (Eds. M.J. Baker, W.M. Williams) CAB International, UK: 493-512.

Watson, R.N.; Skipp, R.A; Barralt. B.I.P. 1968. Initiatives in pest and disease control in New Zealand towards improving legume production and persistence. In Persistence of forage legumes (Eds. G.C. Marten. A.G. Matches, F.F. Barnes. R.W. Brougham, R.J. Clements, G.W. Sheath). Proceedings of a trilateral workshop. Honolulu, Hawaii. American Society of Agronomy, Madison, Wisconsin, USA 


\section{Plant breeding}

Barclay, P.C. 1969. Some aspects of the development and performance of 'grasslands 4700' white clover. Proceedings NZ Grasslands Association 31: 127-34.

Caradus, J.R.; Williams, W.M. 1966. Breeding for legume persistence in New Zealand. In Persistence of forage legumes (eds. G.C. Marten, A.G. Matches, R.F. Barnes, R.W. Brougham, R.J. Clemens, G.W. Sheath). Proceedings of a trilateral workshop, Honolulu. Hawaii. American Society of Agronomy, Madison, Wisconsin, USA.

Davies. W.; Levy. E.B. 1931. Strain investigation of grasses and clovers. 4. White clover (Trifoliumrepens). The NZ Journal of Agriculture 42: 74-89, 151-64.

Van den Bosch, J.; Lancashire, J.A. Cooper, B.M., Lyons, T.B.; Williams, W.M. 1966. G18 white clover - anew cultivar for intensive lowlands. Proceeings NZ Grassland Association 47. 173-78.

White, D.W.R. 1966. Use of cell and molecular genetic manipulation to improve pasture plants. Proceedings NZ Grassland Association 49: 67-72.

Williams, W.M. 1963. White clover. In Plant Breeding in New Zealand (Eds. G.S. Wrath, H.C. Smith): 221-26. 


\begin{tabular}{llllll}
\hline & Plant & Physiology and Morphology & Soil Fertility & \multirow{2}{*}{ Nutrient Cycling Rhirobia Research } \\
& Pasture & Management & N Fixation & \\
\hline $\mathbf{1 8 6 0}$ & & & &
\end{tabular}

Expansion of agriculture through exploitation of

1920

Development of the basic principles of $P$ fertiliser, whiie clover and stock

to increase carrying capacity of the land

$$
\text { Cockayne Levy }
$$

First strain isolation

Advocacy and adoption of principles of soil fertility building.

Reid

1940

1950

\begin{tabular}{|c|c|c|c|}
\hline $\begin{array}{l}\text { Controlled environment } \\
\text { and field studies. } \\
\text { Temperature, and light } \\
\text { responses. Leaf and } \\
\text { stolon growth. }\end{array}$ & $\begin{array}{l}\text { Aerial topdressing } \\
\text { and oversowing. } \\
\text { Hill country } \\
\text { establishment and } \\
\text { management. }\end{array}$ & $\begin{array}{l}\text { Soil organic matt } \\
\text { and } \mathrm{N} \text { inputs. } \\
\text { Walker Adams } \\
\text { Melville Sears } \\
\text { O'connor }\end{array}$ & 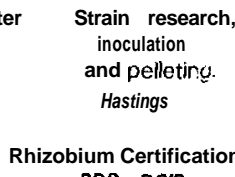 \\
\hline Mitchell Brougham & $\begin{array}{c}\text { Te Awa } \\
\text { Research Area }\end{array}$ & jackman & $P D D \cdot D S I R$ \\
\hline $\begin{array}{ll}\text { Grass/clover } & \text { pasture } \\
\text { management } & \text { strategies. }\end{array}$ & Suckling & & \\
\hline \multicolumn{4}{|l|}{ Brougham } \\
\hline $\begin{array}{l}\text { Treading } \\
\text { Edmond }\end{array}$ & & & $\begin{array}{l}\text { Commercialisation } \\
\text { of inoculation } \\
\text { and pelleting. }\end{array}$ \\
\hline
\end{tabular}

1970

1980

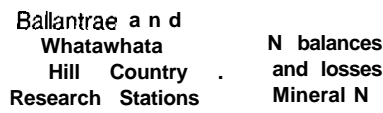

Plant growth and

morphology.

Pascoe

Lambert Sheath

Ball Field Steele

$\mathbf{N}$ fixation - mineral $\mathbf{N}$

interactions

Hoglund

Field competition and

survival of Rhizobia.

Chapman MAF:DSIR Greenwood Pank

Hay Brock

Appendix 1: Schematic representation of the development of white clover research in New Zealand. 


\begin{tabular}{|c|c|c|c|c|}
\hline Soils and & Fertilisers & $\begin{array}{c}\text { Plant Nutrition and } \\
\text { Root Research }\end{array}$ & Plant Breeding & $\begin{array}{c}\text { Pests } \\
\text { and } \\
\text { Diseases }\end{array}$ \\
\hline
\end{tabular}

natural tussock grasslands and clearing of forests.

British Phosphate Commission established and

superphosphate fertiliser accepted for general use.
Classification of soils
and nutrient deficiencies.
Grange Taylor
white clover
Levy Davies Gorman

1860

New Zealand Certified

1930

Root growth

1950

Jacques

Viruses Cunningham

hoculation problems.

$$
\text { Greenwood }
$$

Root cation exchange capacity

Cullen During Mouat
Macity

Grass Grub

Kelsoy

Lime. P, S, Mo interactions.

Walker Adams

Lobb Davies

Plant mineral composition

and diagnostic criteria.

Interplant competition

for nutrients

1960

Kain East French

Nematodes

McNaught Metson

Jackman Mouat

Yeates Grandison

Saunders During

Evans

Mycorrhiza research

Powell Crush

High

analysis fertilisers

PITAU

Barclay

Uptake and metabolism

mechanisms

Alternative phosphate

rock research

Root

Dunfop Hart

morphology

Intraspecific variation

Mackay Dunlop

Caradus

Hart Caradus

TAHORA

Villiams Suckling

KOPU

Williams Barclay 